\title{
A Comprehensive Research on Gamma-Ray Attenuation Characteristics of The Metal-Doped Hap and Natural Animal Bone
}

\author{
Metal Katkılı Hap ve Doğal Hayvan Kemiğinin Gamma-Işını Soğurma Özellikleri Üzerine
} Kapsamlı Bir Araştırma

\author{
Oguz Kagan KOKSAL ${ }^{* 1, a}$, Erhan CENGIZ ${ }^{2, b}$, Ali TOZAR ${ }^{3, \mathrm{c}}$, Ismail Hakki KARAHAN ${ }^{3, d}$, \\ Gokhan APAYDIN ${ }^{1, e}$ \\ ${ }^{I}$ Physics Department, Science Faculty, Karadeniz Technical University, 61080, Trabzon, Turkey \\ ${ }^{2}$ Basic Engineering Science Department, Rafet Kayis Engineering Faculty, Alanya Alaadin Keykubat University, 07450, Antalya, \\ Turkey \\ ${ }^{3}$ Physics Department, Science and Literature Faculty, Hatay Mustafa Kemal University, 31060, Hatay, Turkey
}

• Geliş tarihi / Received: 18.04.2019 • Düzeltilerek geliş tarihi / Received in revised form: 17.09.2019 • Kabul tarihi / Accepted: 4.10.2019

\begin{abstract}
This investigation focuses on the gamma ray attenuation parameters of natural animal bone, iron, cobalt, copper and zinc doped Nano hydroxyapatite artificial bone powders and pure hydroxyapatite. The present specimens were excited by means of gamma ray photons with $59.5 \mathrm{keV}$ energy radiated from a 241-Amercium annular radioactive source with $50 \mathrm{mCi}$ activity by means of narrow beam transmission geometry. The transmitted gamma-rays were counted with using Ultra Low Energy Germanium (Ultra-LEGe) detector with a resolution $150 \mathrm{eV}$ at $5.95 \mathrm{keV}$. The gamma-ray attenuation characteristics such as mass attenuation coefficient (MAC) $(\mu / \rho)$, linear attenuation coefficient (LAC) ( $\mu$ ), half value layer (HVL), tenth value layer (TVL) and mean free path (MFP), which has a significant role in the attenuation studies, are also calculated. The values obtained were checked with the predicted values from the XCOM NIST. The results show that the attenuation data of the metal-doped hydroxyapatite synthetic bone dust is very close to the value of the natural animal bone.
\end{abstract}

Keywords: Gamma-ray Attenuation Parameters, Metal Substituted Hydroxyapatite, Natural Animal Bone

\section{$\ddot{\boldsymbol{O}} z$}

Bu araştırma, doğal hayvan kemiği, demir (Fe), kobalt (Co), bakır (Cu) ve çinko (Zn) katkılı Nano hidroksiapatit yapay kemik tozları ve saf hidroksiapatitin gama ışııı soğurma parametrelerine odaklanmaktadır. Mevcut örnekler, dar bir ışın iletim geometrisi kullanarak $50 \mathrm{mCi}$ aktivitesine sahip 241-Amercium radyoaktif halka şeklindeki bir kaynaktan yayılan $59.5 \mathrm{keV}$ enerjili gama ışını fotonları vasıtasıyla uyarıldı. Numuneden geçen gama ışıları deneysel olarak 5.95 keV'da 150 eV çözünürlüğe sahip Ultra Düşük Enerji Germanyum (Ultra-LEGe) detektörü kullanılarak sayıldı. Kütle

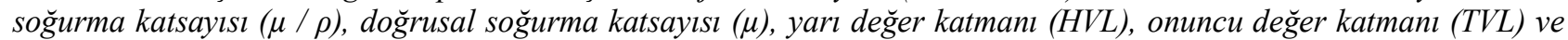
soğurma çalışmalarında önemli bir role sahip olan ortalama serbest yol (MFP) gibi gama ışını soğurma özellikleri hesaplandı. Elde edilen değerler, XCOM NIST'ten tahmin edilen değerlerle kontrol edildi. Sonuçlar, metal katkılı hidroksiapatit sentetik kemik tozunun gama ışını soğurma verilerinin, doğal hayvan kemiğinin değerine çok yakın olduğunu göstermektedir.

Anahtar kelimeler: Gama Işını Soğurma Parametreleri, Metal Katkılı Hidroksiapatit, Doğal Hayvan Kemiği

\footnotetext{
*a Oguz Kagan KOKSAL; okoksal@ktu.edu.tr, orcid.org/0000-0003-2671-6683

${ }^{\mathrm{b}}$ orcid.org/0000-0002-4094-5784 ${ }^{\mathrm{c}}$ orcid.org/0000-0003-3039-1834 ${ }^{\mathrm{d}}$ orcid.org/0000-0002-8297-3521

e orcid.org/0000-0002-4647-344X
} 


\section{Introduction}

Apatite is an ion substitution inorganic compound composed of calcium phosphate. This feature allows it to be used in medical areas (Evis and Webster, 2011). The compound is called as hydroxyapatite (HAp) when the hydroxyly $\left(\mathrm{OH}^{-}\right)$ ion is added to apatite. It is typically expressed as $\mathrm{Ca}_{10}\left(\mathrm{PO}_{4}\right)_{6}(\mathrm{OH})_{2}$. The $\mathrm{Ca} / \mathrm{P}$ molar ratio 1.667 is the critical characteristics for HAp. It is a kind of synthetic compound naturally found in teeth and bone of human and animal (Abutalib and Yahia, 2017; Jadalannagari et al., 2014; Kaygili et al., 2015).

HAp has an important role at implant material in dental and orthopaedic applications (Adzila et al., 2013), bone filler compound since of its biocompatibility (Raucci et al., 2018; Shi et al., 2018), scaffold (Fielding et al., 2012) and metal coating material (Escamilla-Rivera et al., 2016; Farrokhi-Rad et al., 2018; Razavi et al., 2015). In previous research, there are many studies about magnesium, iron, copper, zinc and strontium elements substituted HAp.(Bhattacharjee et al., 2019; Coelho et al., 2019; Othmani et al., 2018; Ullah et al., 2018). It makes its use difficult in medical areas as an implant material since of its poor mechanical properties. To avoid this situation, the various elements are added to pure HAp to get the more strong mechanical property (Badran et al., 2017; Kaygili et al., 2013). Iron, cobalt, copper and zinc metals were doped to pure HAp at 0.5 w.t $\%, 1.0$ w.t $\%, 1.5$ w.t $\%$. There are various causes for doping these metals to pure hydroxyapatite. Iron was substituted to artificial bone dust because it has increased the magnetic facility of the pure HAp. Therefore, this situation can boost medical imaging (Jain et al., 2008). Cobalt was selected for a doped metal because it has a property for treatment of hard tissues and it has a finite magnetic moment in the magnetic field when comparing with diamagnetic hydroxyapatite synthetic bone powder. Besides, zinc and copper metals were doped to the pure HAp to increase since the antimicrobial activity (Chen et al., 2010).

For decades, the radiations have been utilized particularly in the wide range of radiation dosimeter (Gowda et al., 2004), medical physics (Büyüky1ldız and Kurudirek, 2018), radiation biophysics (Gaikwad et al., 2017) and radiation shielding (Gülbiçim et al., 2017). Linear attenuation coefficient (LAC) $(\mu)$, half value layer (HVL), tenth value layer (TVL), and mean free path (MFP) has a significant role to define the effects of gamma radiations for the materials (Tekin et al., 2017). The various investigators (Abbasova et al., 2019; Abutalib and Yahia, 2017; Badran et al., 2017; Kaçal et al., 2018; Köksal et al., 2019) have focused the attenuation parameters of some materials. When considering the former works, the elemental analysis, structural property, mechanical facilities, adsorbing and corrosion were studied by different investigator for some kinds of hydroxyapatite (Ciobanu et al., 2011; Fujii et al., 2006; Koksal et al., 2019a; Stipniece et al., 2018).

The goal of this study is to search gamma ray attenuation characteristics of the real bone and manganese doped hydroxyapatite artificial bone powders. The predicted and experimental results of LAC $(\mu)$, HVL, TVL, and MFP were calculated to search the gamma-ray attenuation parameters. Moreover, the obtained attenuation parameters of the manganese-doped hydroxyapatite have been compared with the value of real bone.

\section{Material and method}

Stoichiometric metal-doped hydroxyapatite nanoparticles were produced by means of wet chemical process. Calcium nitrate tetra hydrate utilized as calcium source and dibasic ammonium phosphate utilized as phosphorous source. 1.0 molar calcium nitrate tetra hydrate and 0.6 molar dibasic ammonium phosphate solutions were arranged by dissolving the salts in distilled water in equal volumes. Ammonium phosphate solution was quietly dropped to calcium nitrate solution drop by drop at a ratio of 5 millilitres in a minute. To prevent rapid sedimentation calcium nitrate solution magnetically mixed by means of the wet chemical process. The $\mathrm{pH}$ amount of the last solution was adjusted to 10 with ammonia and then to 11 with sodium hydroxyl. All of the processes were performed at room temperature. Concentrations of decorated elements (iron, cobalt, copper and zinc), calcium and phosphor for these powders are illustrated in (Koksal et al., 2019a).

The theoretical gamma-ray attenuation parameters were calculated from the former publication (Koksal et al., 2019b). The current specimens were prepared at the same thickness approximately. The mass of the samples was selected as $2000 \mathrm{mg}$ approximately. They were mixed with the cellulose $(0.1 \mathrm{~g})$. Then they were pressed as pellets. The thickness of the sample was defined to get ideal condition (Creagh, 1987) 


\section{$2<\ln \left(\mathrm{I}_{0} / \mathrm{I}\right) \leq 4$}

Narrow beam gamma-ray attenuation set-up is utilized for the attenuation measurements of pure hydroxyapatite, metal-doped hydroxyapatite and natural animal bone which is taken freshly stripped from the butcher's meat. The experimental geometry consisting of the main radioactive source (241-Americium), specimen and detector is illustrated in Figure 1, where the main radioactive source beam is exciting the current specimens and the attenuated beam from the Americium source is transmitted to the detector.

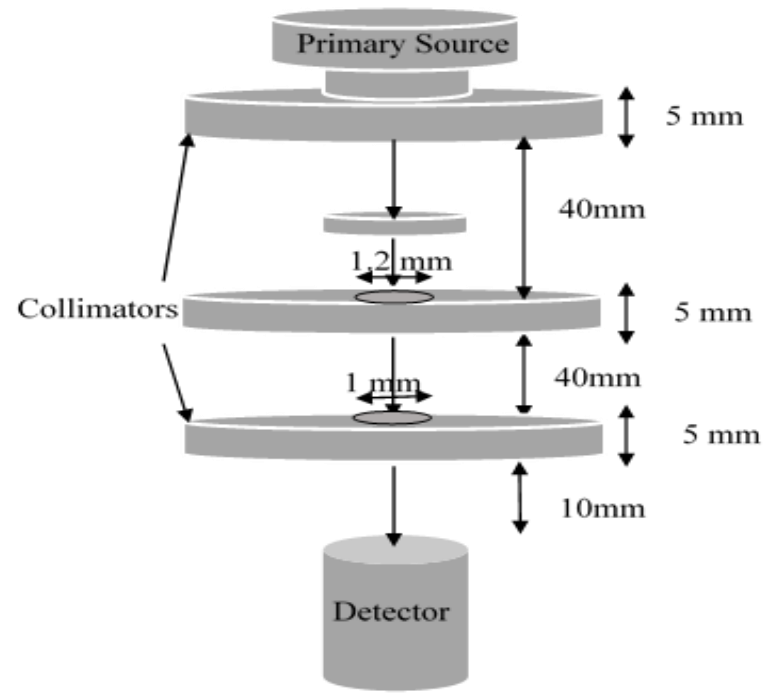

Figure 1. Experimental arrangement for $\mathrm{Am}^{241}$

Three types of the collimators were used for the present geometry. The diameter of the collimators is so important to count the attenuated photons. When the collimator diameter increases, the measured mass attenuation coefficients decreases (Çelik et al., 2012). To avoid gamma ray radiation revealed from nearby objects from reaching the detector, detector is shielded with lead collimators. The diameters of two collimators are 1.2 and $1 \mathrm{~mm}$, respectively. The width of each collimator was adjusted as $6 \mathrm{~mm}$. Specimens were placed on sample holder at a distance of $40 \mathrm{~mm}$ from the primary source and detector.

\section{Theoretical background}

The MAC values were determined by using with expression 2 for available samples. Besides, MAC values were computed by XCOM NIST data base at $59.5 \mathrm{keV}$ energy theoretically (Berger et al., 1999). The values of MAC were computed by using the Lambert-Beer formula for the present specimens (Gowda et al., 2005)
$I=I_{0} e^{-\mu x}=I_{0} e^{-\left(\frac{\mu}{\rho}\right) d}$

where $\mathrm{I}_{0}$; initial beam to the gamma ray detector from the radiation source lack of any absorbance and I; the attenuated beam from the specimen to the detector. $d$ is symbolized as the mass per unit area $\left(\mathrm{g} \cdot \mathrm{cm}^{-2}\right)$ and $\mu / \rho$ is MAC in unit $\left(\mathrm{cm}^{2} \cdot \mathrm{g}^{-1}\right)$. The term of $(\mu / \rho)_{c}$ is calculated by means of the mixture rule for current specimens (Kumar et al., 2019; Sayyed, 2016).

$(\mu / \rho)_{c}=\sum_{i} W_{i}(\mu / \rho)_{i}$

where $\mathrm{W}_{\mathrm{i}}$ is the weight fraction. $(\mu / \rho)_{i}$ is called as the MAC of the ith selecting atom. For any material, the fraction by weight is calculated from using expression (3).

$W_{i}=\frac{n_{i} A_{i}}{\sum_{i} n_{i} A_{i}}$

Where $A_{i}$ and $n_{i}$ are the atomic weight of the ith element and the number of formula units, respectively. LAC $\left(\mu\left(\mathrm{cm}^{-1}\right)\right)$ defines the ratio of the attenuated gamma-ray radiation per unit thickness and determined by following formula.

$\mu=\mu_{m} \rho$

where $\mu_{m}$ is MAC of the specimen and $\rho$ is the density of the compound.

The value of MFP $(\mathrm{cm})$ provides useful information concerned with the gamma-ray photon attenuation. The data of MFP are determined by expression (5) below (El-Bashir et al., 2017).

$M F P=(1 / \mu)$

The term of the HVL $(\mathrm{cm})$ is the thickness of the sample utilized to half the photon beam and identify the capability of gamma ray attenuation for any sample. The half value layer value is calculated by using formula (6) (Issa et al., 2017).

$H V L=\ln 2 / \mu$

The value of TVL $(\mathrm{cm})$ is necessary to decrease the intensity of the gamma ray radiation to onetenth as formulated in following expression (7) (Akman et al., 2019).

$T V L=(\ln 10 / \mu)$

where $\mu$ is the term of LAC. 
The MAC values were used to determine the molecular cross-section $\left(\sigma_{\mathrm{t}, \mathrm{m}}\right)$ by means of expression (8) below.

$\sigma_{t, m}=\frac{1}{N}\left(\frac{\mu}{\rho}\right)_{c} \sum_{i}\left(n_{i} A_{i}\right)$

where $\mathrm{N}$ is named as the avogadro number.

The total atomic cross-section $\left(\sigma_{\mathrm{t}, \mathrm{a}}\right)$ can be calculated by means of the following formula (9)

$\sigma_{t, a}=\frac{\sigma_{t, m}}{\sum_{i} n_{i}}=\frac{1}{N} \sum_{i}\left(f_{i} A_{i}\right)\left(\frac{\mu}{\rho}\right)_{i}$

where $f_{i}=n_{i} / \sum_{i} n_{i}$ is the fractional abundance of element i.

The total electronic cross section $\sigma_{t, e l}$ is formulated with using the expression (10) below for each element

$\sigma_{t, e l}=\frac{1}{N} \sum_{i} \frac{f_{i} A_{i}}{Z_{i}}\left(\frac{\mu}{\rho}\right)_{i}$

where $Z_{i}$ is the atomic number of the ith atom in a material.

The effective atomic number $\left(Z_{\text {eff }}\right)$ is ratio of the total atomic and electronic cross-sections (Sayyed et al., 2018)
$Z_{e f f}=\frac{\sigma_{t, a}}{\sigma_{t, e l}}$

The effective electron density $\mathrm{N}_{\mathrm{el}}$ can be determined by derivation of formulas (2) and (10) (Gowda et al., 2005).

$N_{e l}=\frac{(\mu / \rho)_{c}}{\sigma_{e l}}=\frac{N}{M} Z_{e f f} \sum_{i} n_{i}$

\section{Results and Discussion}

MAC $\left(\mathrm{cm}^{2} / \mathrm{g}\right)$ and LAC $\left(\mathrm{cm}^{-1}\right)$ values, the MFP value $(\mathrm{cm})$, the $H V L$ value $(\mathrm{cm})$, the TVL value $(\mathrm{cm})$, electron density $\left(\mathrm{N}_{\mathrm{el}}\right.$, electrons $\left./ \mathrm{g}\right)$ and effective atomic number $\left(Z_{\text {eff }}\right)$ have been researched for iron, cobalt, copper and zinc-doped Nano hydroxyapatites. Moreover, the natural animal bone was utilized to compare the metaldoped hydroxyapatites. Photon interaction parameters such as HVL, TVL and MFP of the metal doped hydroxyapatites artificial bone powders and the natural animal bone were calculated firstly. The obtained data of gammaray mass attenuation characteristics are listed in Table 1 for the present specimens. Besides, the density is tabulated at the same table.

Table 1. The properties of the gamma-ray attenuation for metal-doped hydroxyapatite artificial bone powders and natural animal bone

\begin{tabular}{|c|c|c|c|c|c|c|c|c|c|c|c|c|}
\hline Specimens & $\mu / \rho$ E. & $\boldsymbol{\mu} / \boldsymbol{\rho}$ * & $\mu^{*}$ & $\mu$ & $\mathbf{N}_{\mathrm{el}} \mathbf{E}$ & $\mathbf{N}_{\mathrm{el}} \mathbf{T}$. & $\mathbf{Z}_{\mathrm{eff}} \mathbf{E}$. & $\mathbf{Z}_{\text {eff }} \mathbf{T}$ & MFP & HVL & TVL & $\begin{array}{c}\text { D } \\
\left(\mathrm{g} / \mathrm{cm}^{3}\right)\end{array}$ \\
\hline Bone & $0.319 \pm 0.025$ & --- & --- & $0.156 \pm 0.013$ & -- & --- & --- & --- & 6.397 & 4.443 & 14.730 & --- \\
\hline nHAp & $0.449 \pm 0.036$ & 0.413 & 0.219 & $0.235 \pm 0.019$ & --- & --- & --- & --- & 4.262 & 2.953 & 19.813 & --- \\
\hline nFeHAp1 & $0.298 \pm 0.024$ & 0.291 & 0.142 & $0.150 \pm 0.012$ & 3.139 & 3.065 & 11.04 & 10.78 & 6.669 & 4.621 & 15.355 & 1.987 \\
\hline nFeHAp2 & $0.288 \pm 0.023$ & 0.305 & 0.150 & $0.147 \pm 0.012$ & 2.985 & 3.161 & 10.63 & 11.26 & 6.800 & 4.712 & 15.657 & 1.884 \\
\hline nFeHAp3 & $0.277 \pm 0.022$ & 0.298 & 0.150 & $0.141 \pm 0.011$ & 2.862 & 3.080 & 10.12 & 10.89 & 7.701 & 4.921 & 16.351 & 1.885 \\
\hline nCoHAp1 & $0.349 \pm 0.028$ & 0.316 & 0.189 & $0.178 \pm 0.014$ & 3.365 & 3.047 & 12.64 & 11.44 & 5.610 & 3.888 & 12.917 & 1.804 \\
\hline nCoHAp2 & $0.325 \pm 0.026$ & 0.319 & 0.155 & $0.164 \pm 0.013$ & 3.081 & 3.024 & 11.63 & 11.42 & 6.115 & 4.238 & 14.080 & 1.891 \\
\hline nCoHAp3 & $0.289 \pm 0.023$ & 0.305 & 0.158 & $0.147 \pm 0.012$ & 2.877 & 3.037 & 10.45 & 11.03 & 6.816 & 4.723 & 15.694 & 1.890 \\
\hline nCuHAp1 & $0.286 \pm 0.023$ & 0.262 & 0.153 & $0.151 \pm 0.012$ & 3.325 & 3.046 & 10.73 & 9.83 & 6.616 & 4.585 & 15.234 & 1.890 \\
\hline nCuHAp2 & $0.299 \pm 0.024$ & 0.322 & 0.157 & $0.149 \pm 0.012$ & 2.812 & 3.029 & 10.56 & 11.37 & 6.705 & 4.647 & 15.439 & 1.895 \\
\hline nCuHAp3 & $0.313 \pm 0.025$ & 0.315 & 0.169 & $0.164 \pm 0.013$ & 3.001 & 3.020 & 11.03 & 11.10 & 6.086 & 4.217 & 14.013 & 1.903 \\
\hline nZnHAp1 & $0.270 \pm 0.022$ & 0.267 & 0.134 & $0.127 \pm 0.010$ & 3.011 & 2.978 & 9.72 & 9.61 & 7.893 & 5.470 & 18.175 & 1.894 \\
\hline nZnHAp2 & $0.278 \pm 0.022$ & 0.250 & 0.148 & $0.147 \pm 0.012$ & 3.375 & 3.035 & 10.20 & 9.18 & 6.814 & 4.722 & 15.691 & 1.891 \\
\hline nZnHAp3 & $0.272 \pm 0.022$ & 0.282 & 0.143 & $0.136 \pm 0.011$ & 2.904 & 3.011 & 9.65 & 10.00 & 7.360 & 5.101 & 16.948 & 1.893 \\
\hline
\end{tabular}


Fig. 2 shows the typical attenuation spectrum for ZnHAp samples.

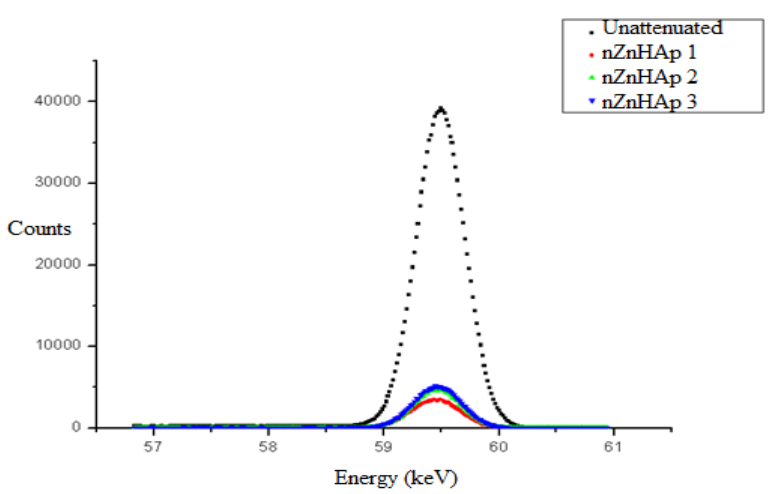

Figure 2. The typical attenuation spectrum for ZnHAp.
Figure 3 provides the variation of experimental MAC and LAC versus samples.

The agreement between the $\mu / \rho$ and $\mu$ values obtained from XCOM is found to be highly acceptable. When looking at the values of present attenuation coefficient it is seen that that experimental values of gamma-ray mass attenuation coefficients are in good agreement with theoretical values. Since there is not any value regarding the gamma-ray attenuation coefficient for any nHAp samples in the previous works, no comparison has been made.

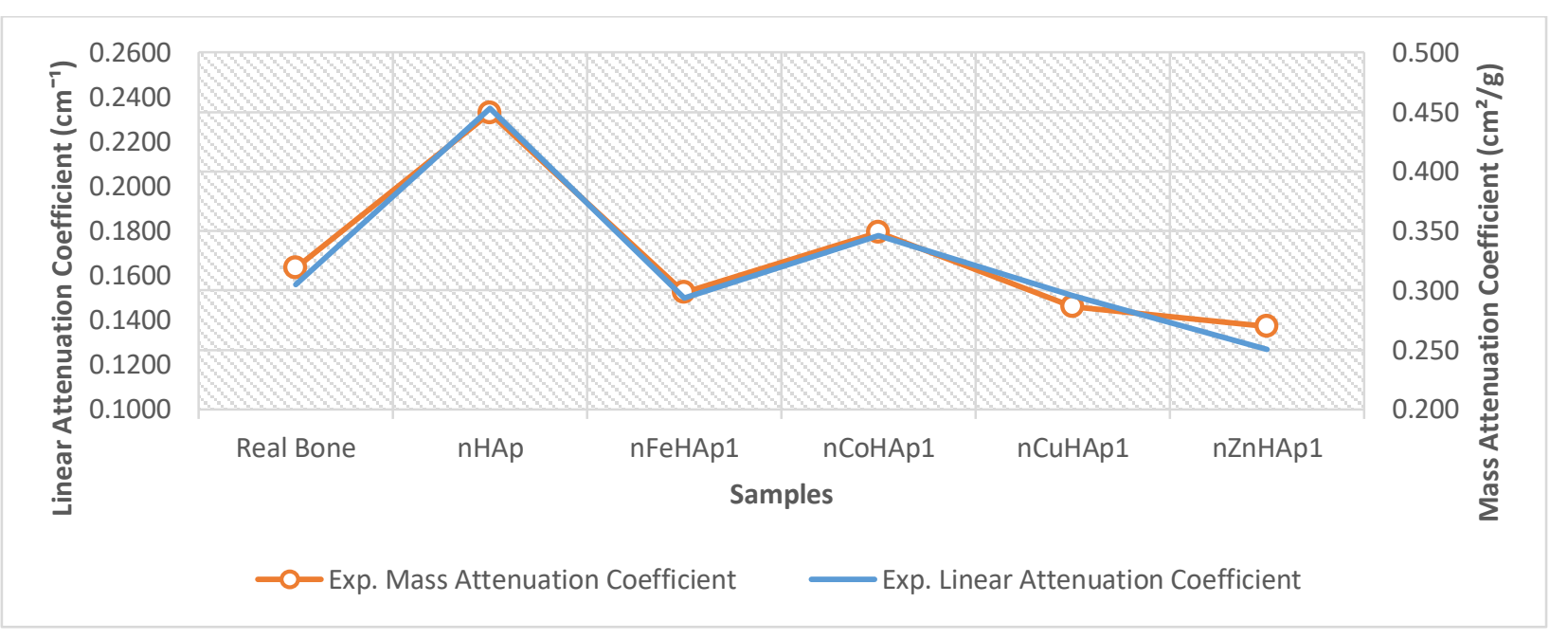

Figure 3. The variation of experimental mass and linear attenuation coefficient for metal doped hydroxyapatites and the natural animal bone with incident energy.

For this reason, this study is thought to be a reference. But it is well known that Bioactive glasses are known as silicate glasses with sodium, calcium and phosphorus as components used to regulate and or support functions of living biological tissues in human body. The advantages of bioactive glasses in physical and mechanical properties enables the use for radiation protection. Following the last few decades from the invention of bioactive glasses, there exists a great of comprehensive scientific research due to its unique biological features namely osteoconduction, anti-inflammatory, antibacterial, osteoinduction and angio-genesis (Bertolla et al., 2017; Jones, 2013). Since of the current values are very close to values of the gamma ray attenuation parameters of bioactive glasses (Tekin et al., 2019), this situation is confirmed that the hydroxyapatite can be very useful for the treatment of the bone. Figure 4 shows the mean free path of the present samples.
The variation of the HVL and TVL is illustrated in Figure 5.

For metal-doped hydroxyapatites, the values of attenuation characteristics such as $\operatorname{MAC}(\mu / \rho)$, LAC ( $\mu)$, MFP, HVL and TVL are very close to the values of the natural animal bone. The reason is that calcium atoms replace doped metal in the production stage. This situation influences the effective atomic number and electron density of the hydroxyapatite artificial bone powder. The deviation in current investigation was estimated to be $\% 8$. This deviation between experimental and predicted values is called as the quadrature sum for uncertainties in the various factors utilized to assess the initial and attenuated photon intensity (\% 5), the thickness of the specimens $\% 2$ and photon detecting statistics $\% 2$. The current research aimed to evaluate the photon attenuation properties of metal-doped hydroxyapatite artificial bone powder and the natural animal bone. 


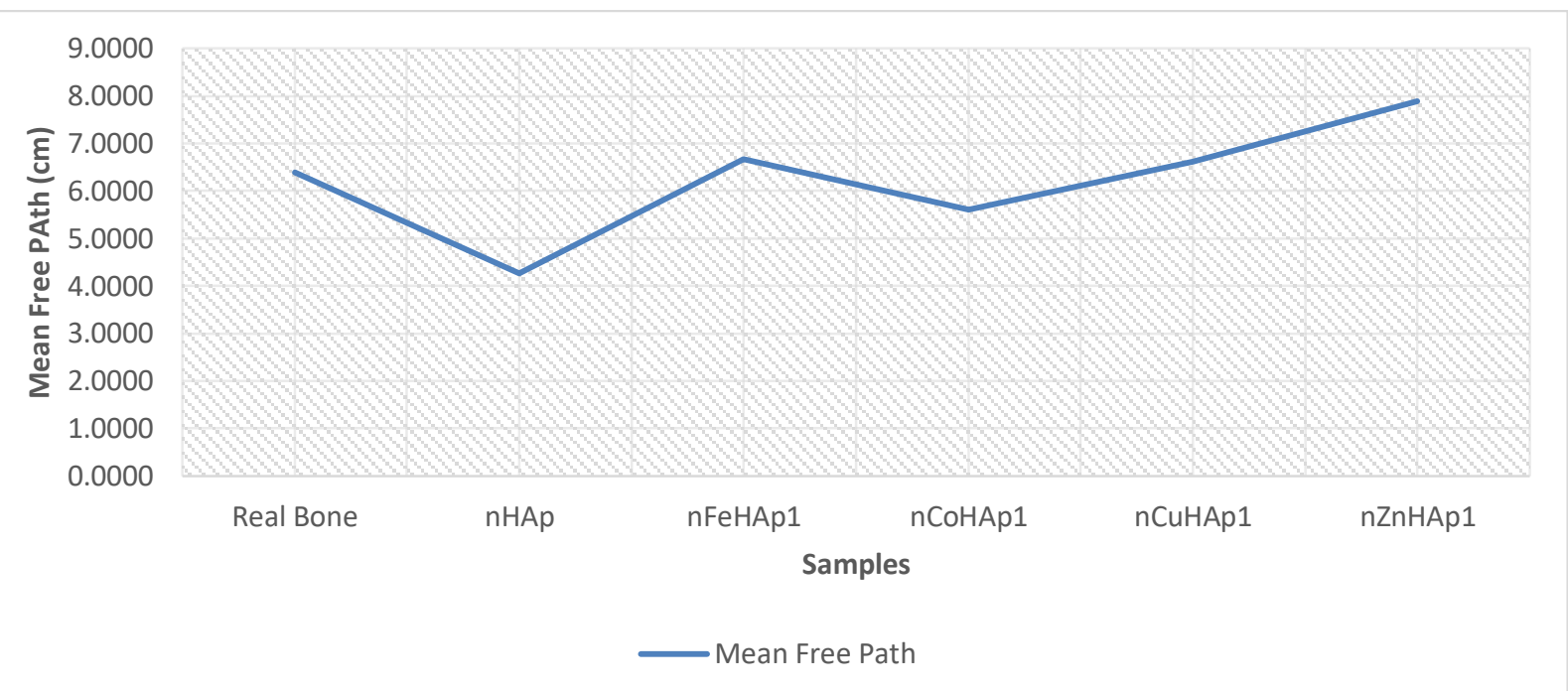

Figure 4. The experimental mean free path versus samples

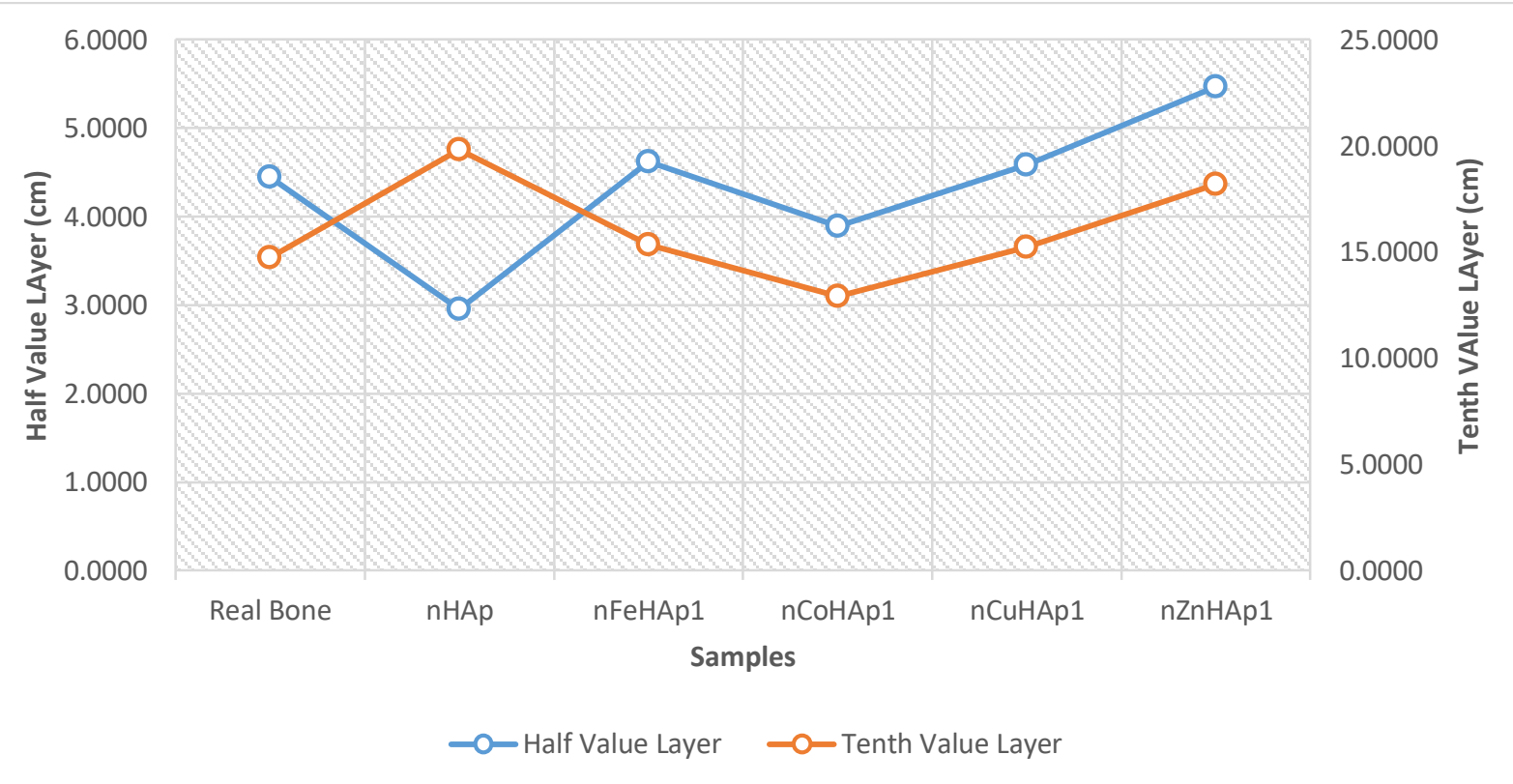

Figure 5. The variation of the half and tenth value layers versus samples

The gamma-ray MAC and LAC for the metaldoped Nano hydroxyapatite artificial bone dust deviate with the predicted attenuation coefficient from XCOM NIST by \% 1-8. The values obtained approve that the experimental result is credible when checked with the theoretical values.

\section{Conclusion}

The values of $\mu / \rho$ and $\mu$ were determined at 59.5 $\mathrm{keV}$ using experimentally and XCOM program. The values of the HVL, the TVL, the MFP, $Z_{\text {eff }}$ and $\mathrm{N}_{\mathrm{el}}$ values that are the significant photon attenuation parameters were obtained. Moreover, the values of metal-doped artificial bone powders were compared with the natural animal bone. The natural animal bone own the almost same value of gamma ray attenuation parameters such as values of LAC, TVL, MFP and HVL for metal doped hydroxyapatites. This is due to the displacement of metals added with calcium atoms. On the other hand, it can be also concluded that metal doped hydroxyapatites artificial bone powders can be candidate treatment materials for medical radiation facilities due to their radiation attenuation properties

\section{References}

Abbasova, N., Yüksel, Z., Abbasov, E., Gülbiçim, H. and Tufan, M.Ç., 2019. Investigation of gammaray attenuation parameters of some materials used in dental applications. Results in Physics, $12,2202-2205$.

Abutalib, M.M. and Yahia, I.S., 2017. Novel and facile microwave-assisted synthesis of Mo-doped 
hydroxyapatite nanorods: Characterization, gamma absorption coefficient, and bioactivity. Materials Science and Engineering: C, 78, 1093-1100.

Adzila, S., Sopyan, I., Singh, R., Pusparini, E. and Hamdi, M., 2013. Mechanochemical synthesis of sodium doped hydroxyapatite powder. Indian Journal of Chemistry, 52, 739-743.

Akman, F., Kaçal, M.R., Sayyed, M.I. and Karataş, H.A., 2019. Study of gamma radiation attenuation properties of some selected ternary alloys. Journal of Alloys and Compounds, 782, 315-322.

Badran, H., Yahia, I.S., Hamdy, M.S. and Awwad, N.S., 2017. Lithium-doped hydroxyapatite nano-composites: synthesis, characterization, gamma attenuation coefficient and dielectric properties. Radiation Physics and Chemistry, 130, 85-91.

Berger, M.J., Hubbell, J.H., Seltzer, S.M., Coursey, J.S. and Zucker, D.S., 1999. XCOM: photon cross section database (version 1.2).

Bertolla, L., Dlouhý, I., Tatarko, P., Viani, A., Mahajan, A., Chlup, Z., Reece, M.J. and Boccaccini, A.R., 2017. Pressureless spark plasma-sintered Bioglass ${ }^{\circledR}$ 45S5 with enhanced mechanical properties and stress-induced new phase formation. Journal of the European Ceramic Society, 37, 2727-2736.

Bhattacharjee, A., Gupta, A., Verma, M., Murugan, P.A., Sengupta, P., Matheshwaran, S., Manna, I. and Balani, K., 2019. Site-specific antibacterial efficacy and cyto/hemo-compatibility of zinc substituted hydroxyapatite. Ceramics International, 45, 12225-12233.

Büyükyıldız, M. and Kurudirek, M., 2018. Radiological properties of healthy, carcinoma and equivalent breast tissues for photon and charged particle interactions. International Journal of Radiation Biology, 94, 70-78.

Chen, Y., Zheng, X., Xie, Y., Ji, H., Ding, C., Li, H. and Dai, K., 2010. Silver release from silvercontaining hydroxyapatite coatings. Surface and Coatings Technology, 205, 1892-1896.

Ciobanu, C.S., Andronescu, E. and Predoi, D., 2011. Bet and XRD Studies on the Hydroxyapatite and Europium Doped Hydroxyapatite. Digest Journal of Nanomaterials and Biostructures, 6, 1239-1244.

Coelho, C.C., Araújo, R., Quadros, P.A., Sousa, S.R. and Monteiro, F.J., 2019. Antibacterial bone substitute of hydroxyapatite and magnesium oxide to prevent dental and orthopaedic infections. Materials Science and Engineering: C, 97, 529-538.

Creagh, D.C., 1987. The resolution of discrepancies in tables of photon attenuation coefficients. Nuclear Instruments and Methods in Physics Research Section A: Accelerators, Spectrometers, Detectors and Associated Equipment, 255, 1-16.

Çelik, N., Çevik, U. and Çelik, A., 2012. Effect of detector collimation on the measured mass attenuation coefficients of some elements for 59.5-661.6 keV gamma-rays. Nuclear Instruments and Methods in Physics Research Section B: Beam Interactions with Materials and Atoms, 281, 8-14.

El-Bashir, B.O., Sayyed, M.I., Zaid, M.H.M. and Matori, K.A., 2017. Comprehensive study on physical, elastic and shielding properties of ternary $\mathrm{BaO}-\mathrm{Bi}_{2} \mathrm{O}_{3}-\mathrm{P}_{2} \mathrm{O}_{5}$ glasses as a potent radiation shielding material. Journal of NonCrystalline Solids, 468, 92-99.

Escamilla-Rivera, V., Uribe-Ramírez, M., EsquivelGaón, M., Rodriguez, L., Giraldo-Betancur, A.L., Campos-Villegas, L., Arreola-Mendoza, L., Muñoz-Saldaña, J. and Ruiz, A.D.V., 2016. Biomimetic titania/hydroxyapatite coating of CrCoMo microimplants enhances biocompatibility and reduces metal-associated toxicity. Toxicology Letters, 259, S154.

Evis, Z. and Webster, T., 2011. Nanosize hydroxyapatite: doping with various ions. Advances in Applied Ceramics, 110, 311-321.

Farrokhi-Rad, M., Khosrowshahi, Y.B., Hassannejad, H., Nouri, A. and Hosseini, M., 2018. Preparation and characterization of hydroxyapatite/titania nanocomposite coatings on titanium by electrophoretic deposition. Materials Research Express, 5, 115004.

Fielding, G.A., Roy, M., Bandyopadhyay, A. and Bose, S., 2012. Antibacterial and biological characteristics of silver containing and strontium doped plasma sprayed hydroxyapatite coatings. Acta Biomaterialia, 8, 3144-3152.

Fujii, E., Kawabata, K., Ando, K., Tsuru, K., Hayakawa, S. and Osaka, A., 2006. Synthesis and structural characterization of silicahybridized hydroxyapatite with gas adsorption capability. Journal of the Ceramic Society of Japan, 114, 769-773.

Gaikwad, D.K., Pawar, P.P. and Selvam, T.P., 2017. Mass attenuation coefficients and effective atomic numbers of biological compounds for gamma ray interactions. Radiation Physics and Chemistry, 138, 75-80. 
Gowda, S., Krishnaveni, S. and Gowda, R., 2005. Studies on effective atomic numbers and electron densities in amino acids and sugars in the energy range 30-1333 keV. Nuclear Instruments and Methods in Physics Research Section B: Beam Interactions with Materials and Atoms, 239, 361-369.

Gowda, S., Krishnaveni, S., Yashoda, T., Umesh, T.K. and Gowda, R., 2004. Photon mass attenuation coefficients, effective atomic numbers and electron densities of some thermoluminescent dosimetric compounds. Pramana, 63, 529-541.

Gülbiçim, H., Tufan, M.Ç. and Türkan, M.N., 2017. The investigation of vermiculite as an alternating shielding material for gamma rays. Radiation Physics Chemistry, 130, 112-117.

Issa, S.A.M., Hamdalla, T.A. and Darwish, A.A.A., 2017. Effect of $\mathrm{ErCl}_{3}$ in gamma and neutron parameters for different concentration of $\mathrm{ErCl}_{3}$ $\mathrm{SiO}_{2}$ (EDFA) for the signal protection from nuclear radiation. Journal of Alloys and Compounds, 698, 234-240.

Jadalannagari, S., Deshmukh, K., Ramanan, S.R. and Kowshik, M., 2014. Antimicrobial activity of hemocompatible silver doped hydroxyapatite nanoparticles synthesized by modified sol-gel technique. Applied Nanoscience, 4, 133-141.

Jain, T.K., Richey, J., Strand, M., Leslie-Pelecky, D.L., Flask, C.A. and Labhasetwar, V., 2008. Magnetic nanoparticles with dual functional properties: Drug delivery and magnetic resonance imaging. Biomaterials, 29, 40124021.

Jones, J.R., 2013. Review of bioactive glass: from Hench to hybrids. Acta Biomaterialia 9, 44574486.

Kaçal, M.R., Akman, F. and Sayyed, M.I., 2018. Evaluation of gamma-ray and neutron attenuation properties of some polymers. Nuclear Engineering and Technology,51, 818824.

Kaygili, O., Keser, S., Ates, T., Al-Ghamdi, A.A. and Yakuphanoglu, F., 2013. Controlling of dielectrical and optical properties of hydroxyapatite based bioceramics by $\mathrm{Cd}$ content. Powder Technology, 245, 1-6.

Kaygili, O., Keser, S., Ates, T., Tatar, C. and Yakuphanoglu, F., 2015. Controlling of dielectric parameters of insulating hydroxyapatite by simulated body fluid. Materials Science and Engineering: C, 46, 118124.

Koksal, O., Wrobel, P., Apaydin, G., Cengiz, E., Lankosz, M., Tozar, A., Karahan, I., Özkalayci,
F., 2019a. Elemental analysis for iron, cobalt, copper and zinc decorated hydroxyapatite synthetic bone dusts by EDXRF and SEM. Microchem J 144, 83-87.

Koksal, O.K., Apaydın, G., Tozar, A., Karahan, İ.H. and Cengiz, E., 2019b. Assessment of the mass attenuation parameters with using gamma-rays for manganese substituted nano hydroxyapatite. Radiation Physics and Chemistry, 159, 76-80.

Köksal, O.K, Cengiz, E., Apaydın, G., Tozar, A. and Karahan, İ., 2019. Determination of the Mass Attenuation Coefficient, Effective Atomic Number and Electron Density for Nano Manganese Hydroxyapatite by using 778-1457 keV Gamma Rays. Journal of Nuclear Sciences, $5,24-29$.

Kumar, A., Kaur, R., Sayyed, M.I., Rashad, M., Singh, M. and Ali, A.M., 2019. Physical, structural, optical and gamma ray shielding behavior of $(20+\mathrm{x}) \mathrm{PbO}-10 \mathrm{BaO}-10 \mathrm{Na}_{2} \mathrm{O}-10 \mathrm{MgO}-$ $(50-\mathrm{x}) \mathrm{B}_{2} \mathrm{O}_{3}$ glasses. Physica $\mathrm{B}$ : Condensed Matter, 552, 110-118.

Othmani, M., Bachoua, H., Ghandour, Y., Aissa, A. and Debbabi, M., 2018. Synthesis, characterization and catalytic properties of copper-substituted hydroxyapatite nanocrystals. Materials Research Bulletin, 97, 560-566.

Raucci, M.G., Demitri, C., Soriente, A., Fasolino, I., Sannino, A. and Ambrosio, L., 2018. Gelatin/nano-hydroxyapatite hydrogel scaffold prepared by sol-gel technology as filler to repair bone defects. Journal of Biomedical Materials Research Part A, 106, 2007-2019.

Razavi, M., Fathi, M., Savabi, O., Vashaee, D. and Tayebi, L., 2015. In Vitro Analysis of Electrophoretic Deposited Fluoridated Hydroxyapatite Coating on Micro-arc Oxidized $\mathrm{AZ}_{91}$ Magnesium Alloy for Biomaterials Applications. Metallurgical Materials Transactions A, 46, 1394-1404.

Sayyed, M.I., 2016. Bismuth modified shielding properties of zinc boro-tellurite glasses. Journal of Alloys and Compounds, 688, 111-117.

Sayyed, M.I., Akman, F., Geçibesler, I.H. and Tekin, H., 2018. Measurement of mass attenuation coefficients, effective atomic numbers, and electron densities for different parts of medicinal aromatic plants in low-energy region. Nuclear Science and Techniques, 29, 144, 1-10.

Shi, P., Liu, M., Fan, F., Yu, C., Lu, W. and Du, M., 2018. Characterization of natural hydroxyapatite originated from fish bone and its biocompatibility with osteoblasts. Materials Science and Engineering: C, 90, 706-712. 
Stipniece, L., Stepanova, V., Narkevica, I., SalmaAncane, K. and Boyd, A.R., 2018. Comparative study of surface properties of Mg-substituted hydroxyapatite bioceramic microspheres. Journal of the European Ceramic Society, 38, 761-768.

Tekin, H.O., Singh, V.P and Manici, T.,2017. Effects of micro-sized and nano-sized $\mathrm{WO}_{3}$ on mass attenauation coefficients of concrete by using MCNPX code. Applied Radiation and Isotopes, 121, 122-125.
Tekin, H.O., Kavaz, E., Altunsoy, E.E., Kilicoglu, O., Agar, O., Erguzel, T.T. and Sayyed, M.I., 2019. An extensive investigation on gamma-ray and neutron attenuation parameters of cobalt oxide and nickel oxide substituted bioactive glasses. Ceramics International, 45, 9934-9949.

Ullah, I., Li, W., Lei, S., Zhang, Y., Zhang, W., Farooq, U., Ullah, S., Ullah, M.W. and Zhang, X., 2018. Simultaneous co-substitution of $\mathrm{Sr}^{2+} / \mathrm{Fe}^{3+}$ in hydroxyapatite nanoparticles for potential biomedical applications. Ceramics International 44, 21338-21348. 